\title{
Developing Metacognitive Skills in PBL Undergraduate Engineering
}

\section{Prof. Rose M. Marra, University of Missouri}

Rose M. Marra is a Professor of Learning Technologies at the University of Missouri. She is PI of the NSF-funded Supporting Collaboration in Engineering Education, and has studied and published on engineering education, women and minorities in STEM, online learning and assessment. Marra holds a $\mathrm{PhD}$. in Educational Leadership and Innovation and worked as a software engineer before entering academe.

\section{Dr. Carolyn Plumb, Montana State University}

Carolyn Plumb is the recently retired Director of Educational Innovation and Strategic Projects in the College of Engineering at Montana State University (MSU). Plumb has been involved in engineering education and program evaluation for over 25 years, and she continues to work on externally funded projects relating to engineering education.

\section{Dr. Douglas J. Hacker}

Dr. Hacker is a full professor in the Department of Educational Psychology and participates in both the Learning Sciences Program and the Reading and Literacy Program. Prior to receiving his Ph. D. in educational psychology from the University of Washington in 1994, Dr. Hacker worked as a high school science and math teacher and then as a school counselor. From 1994 to 1999, Dr. Hacker was an assistant/associate professor in the Department of Counseling, Educational Psychology and Research at The University of Memphis. During those years, he worked in the areas of reading and writing processes, metacognition, self-regulated learning, teacher education, and school and program evaluation. Dr. Hacker moved to the University of Utah in 1999 and has continued his research in the previous areas and has added to them research in the area of the detection of deception. Also at the University of Utah, he served as chair of the Teaching and Learning Department. His publications have appeared in the Journal of Educational Psychology, Contemporary Educational Psychology, Journal of Experimental Psychology: Applied, and Journal of Experimental Education. At both universities, Dr. Hacker has maintained a strong commitment to work in elementary and middle schools, working directly with teachers by providing professional development in reading and writing instruction. He has served as an editorial board member for the Journal of Educational Psychology, Metacognition and Learning, and Frontiers of Educational Psychology. He is a former Associate Editor for the Journal of Educational Psychology. 


\title{
Developing Metacognitive Skills in PBL Undergraduate Engineering
}

\author{
Introduction and Background
}

Metacognition is "knowledge of one's knowledge, processes, and cognitive and affective states; and the ability to consciously and deliberately monitor and regulate one's knowledge, processes, and cognitive and affective states" [1]. Metacognition is key to developing self-directed learning skills that are foundational to ABET's required "ability to be a life-long learner." Self-directed learning is also necessary for an effective work career, yet it is rarely integrated into engineering education [2].

In our IUSE NSF project, we are studying the development of metacognitive and self-directed learning skills of students and graduates of the Iron Range Engineering program (IRE). IRE is an innovative, problem-based-learning (PBL) engineering program in Virginia, Minnesota, where students explicitly engage in activities to become aware of and develop metacognitive and selfdirected learning skills and apply them in the context of real-world problem solving.

Metacognition and Self-Directed Learning in Engineering

Metacognition, originally referred to as "knowledge and cognition about cognitive phenomena" [3], is a higher-order thinking skill and provides the key to developing life-long learning skills necessary for ABET and for an effective engineering work career. Metacognition is generally recognized as having both declarative and procedural components. The declarative aspect of metacognition is made up of a person's knowledge about one's self as a learner while the procedural knowledge is the ability to monitor and control one's learning [4], [5].

Self-directed learning is defined by Knowles [6] as "a process in which individuals take the initiative, with or without the help of others, in diagnosing their learning needs, formulating their learning goals, identifying human and material resources for learning, choosing and implementing appropriate learning ...".

Self-directed learning is often described in terms of the four components represented in Figure 1 [7]. The relationship between self-directed learning and metacognition is generally recognized as metacognitive skills being necessary to become a successful self-directed learner. As Figure 1 shows, all four quadrants of self-directed learning require the monitoring and control of skills that are supported by the procedural aspect of metacognition. 


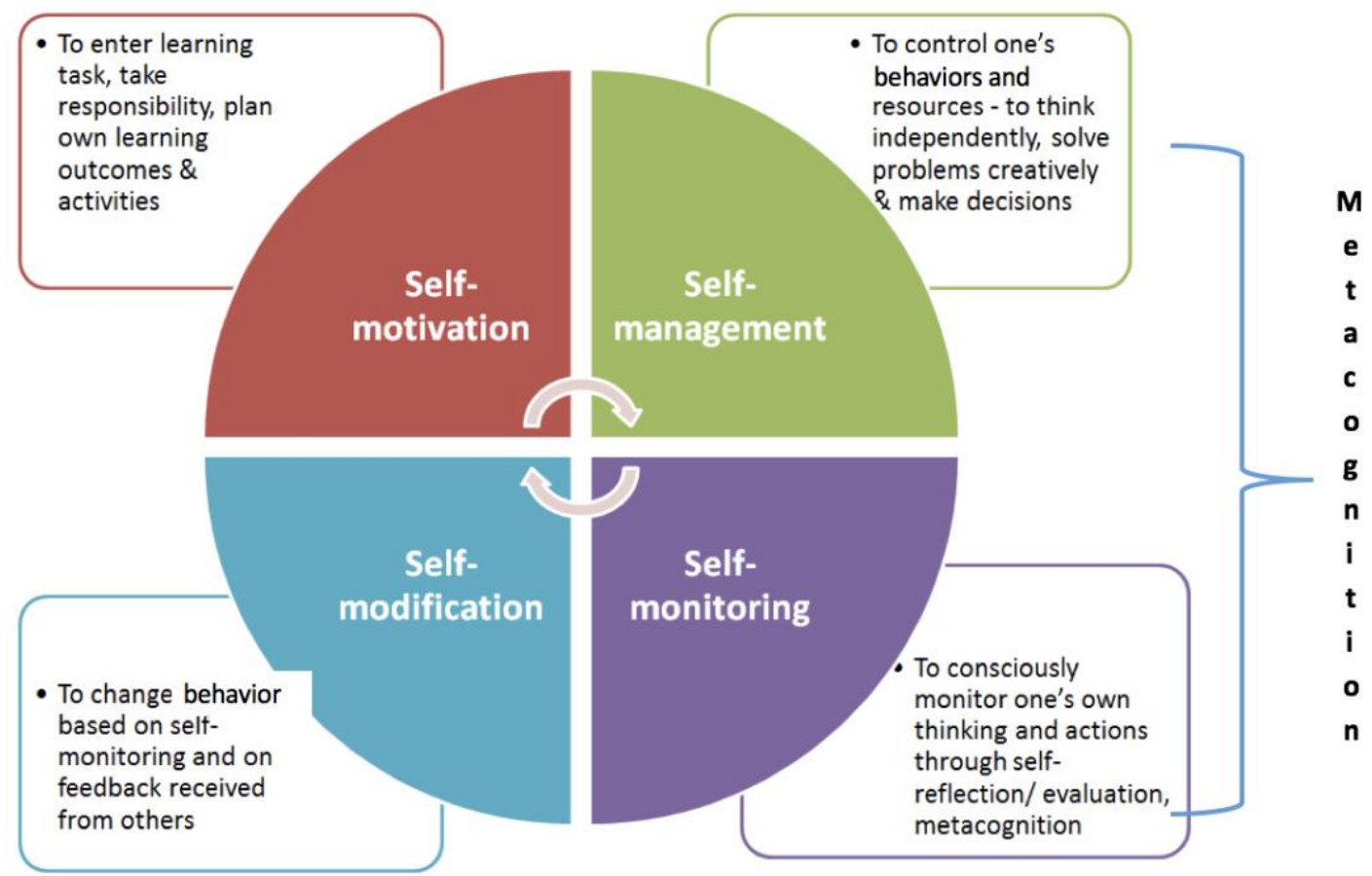

Figure 1. Aspects of Self-Directed Learning (SDL) and How Metacognition Supports SDL

Studies show there is a gap between what graduating engineers can do and what employers want. Engineers are primarily hired and rewarded for solving ill-structured problems [8], [9]. Illstructured problems are context and content dependent [10] and require the ability to generate a variety of novel solutions (no single solution is necessarily right or wrong) and to decide which solution is the best for the given problem in the given context [11]. Thus, engineers must have the metacognitive skills and be able to self-direct their problem solving activities to negotiate the problems they encounter in practice.

In a prior paper [12], we reported on data from alumni of IRE who participated in our study and described how their preparation at IRE had impacted their transition to the workplace. The majority of graduates reported on the advantages of the similarity between the IRE projects and their workplace engineering problem solving activities, their developed ability to apply metacognitive strategies to engineering problem solving, and their openness to the uncertainty of problem solving in real-world settings. While the prior study reported results from IRE alumni, this paper/poster focuses on the development of self-directed learning skills of IRE students.

\section{The Iron Range Engineering Program}

The IRE program is a completely problem-based learning curriculum for upper-division (junior and senior) students. Rather than take lecture-based courses about engineering, IRE students work in teams to solve complex and ill-structured problems for local industries. To direct their work, students generate (with the help of faculty) a series of syllabi that describe how they will meet the demands from the ill-structured problems presented to them from local industries and the technical and design competencies that comprise the IRE curriculum. A majority of IRE learning and assessment activities are organized and indexed by the aforementioned team-based, 
semester-long industry projects. Students have a wide variety of resources available to them to support their learning. These resources span the spectrum from printed materials and electronic libraries to external practicing experts and faculty.

Throughout their learning, students must make their own decisions to determine how best to proceed to complete their tasks. To support students in developing and engaging in self-directed learning, students regularly engage in explicit metacognitive focused reflection activities. For instance, students may complete a metacognitive memo to reflect on the strategies used for a problem solving activity. The overall process of engaging in their self-directed learning includes organizing and documenting their learning as it happens, reflecting on the learning and learning processes on a frequent basis, making qualitative judgments on the quality of the learning, and then making regulative changes to their learning strategies based on their judgments.

\section{Methods}

Participants and Procedure. We have been in the process of collecting interview data from two cohorts of IRE students. The year of students' participation in the program is omitted for purposes of anonymity; however, each cohort contained approximately 15 students. For each cohort we collected interview data at the beginning and at the end of their program. Because the IRE program is a two-year program for the third and fourth years of an engineering degree, we collect data at the beginning of the junior year and at the end of the senior year.

Because the cohorts are relatively small, we interview all members of the cohort using a semistructured interview protocol. Interviews are face to face and recorded for later verbatim transcriptions. The interview protocol addresses the following topics.

- Background information such as why they chose to attend IRE, and their prior college preparation.

- General approaches to self-directing their learning

- Specific techniques they use that they find useful

- Perceptions of what metacognition and self-directed learning are

- Perception of the value of metacognition and self-directed learning.

In the second interview, we addressed the same topics and also asked students to reflect on how their strategies and approaches to self-directed learning and applying metacognitive skills had changed during their time at IRE.

Analysis. To analyze the interview data, audio recordings were transcribed, and we loaded the files into Dedoose (a cloud-based qualitative analysis system, dedoose.com) for coding. Two researchers read through all of the "pre" interview data collected. The purpose of the initial reading was to note general themes that emerged from the data. We noted both themes related to metacognition but also noted other things that consistently arose in students' comments. Researchers then met to create and define a list of codes to apply to the interviews. Table 1 shows a summary of the coding categories we used. 
Table 1. Summary of Coding Categories

\begin{tabular}{|l|l|}
\hline Code & Description \\
\hline \hline IRE Learning Environment & $\begin{array}{l}\text { Comments about class size, pedagogical approach, instructor } \\
\text { access. }\end{array}$ \\
\hline $\begin{array}{l}\text { Self-directed learning } \\
\text { definition }\end{array}$ & $\begin{array}{l}\text { Student's description and understanding of what self-directed } \\
\text { learning is. }\end{array}$ \\
\hline $\begin{array}{l}\text { Self-directed learning } \\
\text { strategies }\end{array}$ & $\begin{array}{l}\text { Descriptions of strategies and tools students use to self-direct } \\
\text { their learning. }\end{array}$ \\
\hline $\begin{array}{l}\text { Self-directed learning Self- } \\
\text { assessment }\end{array}$ & $\begin{array}{l}\text { Student's self- assessment of their self-directed learning } \\
\text { abilities. }\end{array}$ \\
\hline $\begin{array}{l}\text { Prior experiences with self } \\
\text { directed learning }\end{array}$ & $\begin{array}{l}\text { Students' description of using self-directed learning prior to } \\
\text { coming to IRE }\end{array}$ \\
\hline $\begin{array}{l}\text { Perceived value of self- } \\
\text { directed learning }\end{array}$ & $\begin{array}{l}\text { Students' understanding of the value of self-directed learning in } \\
\text { their studies and future careers }\end{array}$ \\
\hline
\end{tabular}

At this writing we have coded all of the first interviews for both cohorts, and have just collected second interview data from the first cohort.

\section{Current Results}

Given that we have just recently collected our second interviews with our first cohort of students, complete coded analyses are not available for these new interviews. Thus, this paper reports a high-level comparison of two students pre and post interviews, using codes from Table 1 as points of comparison.

Tables 2 and 3 show several excerpt comparisons from the first and second interviews for both students. Student A is studying Electrical Engineering as an emphasis area. This student had begun his/her college studies at another local community college before transferring to IRE for the third and fourth years of study. Student B had also started his/her college studies at the same community college and was studying Mechanical Engineering at IRE. Both students had also participated in co-ops during their time at IRE. 
Table 2. Student A Pre and Post Interview Excerpts

\begin{tabular}{|l|l|l|}
\hline $\begin{array}{l}\text { SDL } \\
\text { definition }\end{array}$ & $\begin{array}{l}\text { Feaching yourself and learning concepts that would } \\
\text { be useful in daily life and in a career. By reaching } \\
\text { out to sources that are readily available. }\end{array}$ & $\begin{array}{l}\text { It's my ability to teach myself anything that I need to know } \\
\text { and to also know where to find the information so if I don't } \\
\text { know something, I know how to find information on it, } \\
\text { which includes online resources, textbooks, industry } \\
\text { professionals. Also, how to retain the information. }\end{array}$ \\
\hline Reflection & $\begin{array}{l}\text { No mention } \\
\text { I'm working currently and I try to incorporate reflecting on } \\
\text { things at work as well. It's hard because I sometimes I feel } \\
\text { like people probably wonder like "Oh, you're not really } \\
\text { working" but I've seen the value that it has and the results it } \\
\text { can have when you just take a few minutes and like reflect } \\
\text { on something that you did. For me, I'm better at doing } \\
\text { things repeatedly. If I can reflect on something that I } \\
\text { learned a couple of times it helps }\end{array}$ \\
\hline $\begin{array}{l}\text { SDL value } \\
\text { you want to learn so it's you taking control of what } \\
\text { you want to learn and going out and learning it. I } \\
\text { think that is going to be crucial here because no one } \\
\text { knowledge when I graduate. }\end{array}$ & $\begin{array}{l}\text { Huge. Everything is so new and the industry is continually } \\
\text { changing. Being able to adapt to those changes is going to } \\
\text { make me very valuable. Part of adapting is understanding } \\
\text { how to learn as I'm going. I think that the self-directed } \\
\text { learning is going to be a HUGE asset and it already is. I } \\
\text { had a review a couple of months back and I noticed my } \\
\text { supervisor commenting that I'm really good about being } \\
\text { able to reach out to other sources first and then organize the } \\
\text { information so that I can look it up again quickly if I need } \\
\text { to. }\end{array}$ \\
\hline
\end{tabular}


Table 3. Student B Pre and Post Interview Excerpts

\begin{tabular}{|c|c|c|}
\hline & First Interview Excerpts & Second Interview Excerpts \\
\hline $\begin{array}{l}\text { SDL } \\
\text { definition }\end{array}$ & $\begin{array}{l}\text { To be completely independent and if you wanted to } \\
\text { learn something, you would identify the need, the } \\
\text { problem, the desire to learn a topic for whatever } \\
\text { reason. Once you find that topic then you look for } \\
\text { resources to learn from about that topic. Those } \\
\text { resources could be a person (teacher, author), } \\
\text { online, textbooks (online, library), videos } \\
\text { (YouTube) ... You look through all of these and you } \\
\text { find your specific topic and maybe specific points } \\
\text { that you identified through your need and want. }\end{array}$ & $\begin{array}{l}\text { I think self-directed is having the ability to find the } \\
\text { resources you need to learn about a topic. It's necessarily } \\
\text { mean learning something by yourself like sitting in a room } \\
\text { with nobody in a room and you have to figure out a } \\
\text { problem. ..... It's also knowing which options are } \\
\text { appropriate. It might not be worth my time to go bother } \\
\text { someone to just google the definition of a word or } \\
\text { something like that. It's just knowing when to use which. } \\
\text { Maybe it's something broad and I don't even know the } \\
\text { question. In that case I might want to seek a person. }\end{array}$ \\
\hline $\begin{array}{l}\text { Strategies - } \\
\text { time }\end{array}$ & $\begin{array}{l}\text { I keep a planner. The second I hear about homework } \\
\text { or something due, I write it down immediately. I'm } \\
\text { consistently looking through that planner throughout } \\
\text { the whole day and am constantly updating it. I keep } \\
\text { sticky notes on my computer. I have a sticky note } \\
\text { with a To-Do list which I'm constantly revising and } \\
\text { trying to keep up with it while meeting deadlines. } \\
\text { Another strategy is to look at a full sized calendar } \\
\text { that IRE has in the lecture room downstairs ... }\end{array}$ & $\begin{array}{l}\text { Yes, it's a spreadsheet adapted into a calendar and I just } \\
\text { chunk times out for different task. Its color coordinated and } \\
\text { I religiously look at that ..A have a short term one and a } \\
\text { long term one. It's something I use not only for school but } \\
\text { for my job and my career goals and many other aspects. I } \\
\text { even have one for working out. It's almost like a big project } \\
\text { management chart that I use and that I definitely learned at } \\
\text { IRE and is something that has been a useful tool for me. I } \\
\text { really expanded on it and focus on using that a lot. It's } \\
\text { definitely something I'll use post-graduation. }\end{array}$ \\
\hline $\begin{array}{l}\text { Importance } \\
\text { of SDL }\end{array}$ & $\begin{array}{l}\text { Yes, it's very important. It's important because it } \\
\text { gives me the freedom to learn what I want which } \\
\text { helps me be interested in a certain topic. It's also } \\
\text { more satisfying because I figured it out and it really } \\
\text { sticks since I had to dig for it. }\end{array}$ & $\begin{array}{l}\text { I think my IRE experience really helped me. I think it really } \\
\text { helped me with my autonomy, just having that freedom of } \\
\text { making your own path. I think a part of that for me is I } \\
\text { when you're so put in a confining box, ... I like to be the } \\
\text { controller and a leadership role to have that freedom of } \\
\text { creativity. Even the schedule. If I have that I'm far more } \\
\text { productive and far more contributing. I think IRE really } \\
\text { allowed me to realize I can do that not only in school but } \\
\text { however I chose to pursue whatever it is I am pursuing. I } \\
\text { think that's my really large theme take away from IRE. }\end{array}$ \\
\hline
\end{tabular}


In our examination of these excerpts we can see evidence of the development of these students' understanding and application of the tactics and approaches associated with self-directed learning in which they have engaged during their time at IRE. Specifically we observe the following:

Evidence of more nuanced and sophisticated understandings of self-directed learning. Looking at Student B, we can see this evidence very clearly. In the "SDL definition" row one, we see that in the first interview, this student describes self-directed learning in very procedural terms. In contrast, in the second interview, we see that this student has expanded her understanding to include aspects of metacognitive control. Note that the statement of "It's also knowing which options are appropriate," shows evidence that this student knows that applying self-directed learning strategies is not a rigid procedure, but one that requires reflection based on context and circumstances.

Although not speaking directly about self-directed learning, Student A offered his thoughts on the value of engaging in reflection as part of learning. This student had not mentioned the importance or the use of reflection in the first interview, but offered in the second interview that he is "incorporating reflection" in work activities and how this process helps him to be able to more deeply internalize what was learned.

Broader understanding of the importance of self-directed learning. Both Students broadened their understanding of the importance of self-directed learning during their time at IRE. Student B describes self-directed learning as a tool that can help provide an ability for her to be in control over his life. He describes the skills at IRE as helping him to be able to have "autonomy" over the path he chooses, and that the skills he has learned can be applied to "whatever it is I am pursuing." Similarly, Student A describes how self-directed learning skills are already having a positive impact on his experiences in his work environment.

Application of self-directed learning principles beyond school and work. Although we only see this clearly in Student B, it is worth noting that this student is applying time management strategies from school to her life outside of school and work. Referring to a color-coded calendar, she says: "I use not only for school but for my job and my career goals and many other aspects. I even have one for working out." This extension of strategies to non-school settings indicates this student has both internalized the strategy but also evaluated it and found it worthwhile to apply more broadly.

\section{Future Directions and Conclusions}

Becoming a self-directed learner is integral to achieving the ABET goal of graduating students who can be life-long learners. Our project is studying the development of metacognitive and selfdirected learning skills in a unique problem-based curriculum at the Iron Range Engineering program. This paper has described one aspect of our data collection - beginning and end of program interviews with two IRE cohorts. We report on preliminary results of a comparison of the end-of-program interviews with the same students' beginning interviews. 
Our results show evidence of both students developing in positive ways in their understanding and application of self-directed learning and related skills. These results are promising preliminary evidence for the effectiveness of the instructional tactics being used at IRE to develop self-directed learning and metacognitive skills. Our continued analysis will include comparative analysis of all the beginning and end-of-program student interviews. These results will be analyzed alongside the think-aloud problem solving results and IRE alumni interviews to produce a complete picture of how this program supports the development of self-directed learning and metacognitive skills, to what extent these transfer to the workplace and how these innovations might be scalable to other engineering curricula. 


\section{References}

[1] D. Hacker, J. Dunlosky and A. Graesser, Metacognition in educational theory and practice. Mahwah, N.J.: L. Erlbaum Associates, 1998.

[2] E. Redish and K. Smith, "Looking Beyond Content: Skill Development for Engineers", Journal of Engineering Education, vol. 97, no. 3, pp. 295-307, 2008.

[3] J. Flavell, "Metacognition and cognitive monitoring: A new area of cognitive-developmental inquiry.", American Psychologist, vol. 34, no. 10, pp. 906-911, 1979.

[4] T. O.Nelson and L. Narens, "Metamemory: A theoretical framework and some new findings", The psychology of learning and motivation. New York: Academic Press, pp. 125-173, 1990.

[5] T. Nelson and L. Narens, "Metamemory: A theoretical framework and new findings." In T. O. Nelson (Ed.), Metacognition: Core readings. Boston: Allyn and Bacon, pp. 117-129, 1992.

[6] M. Knowles, "SELF-DIRECTED LEARNING: A GUIDE FOR LEARNERS AND TEACHERS",New York: Association Press, 1975. 135 pp., paperbound", Group \& Organization Studies, vol. 2, no. 2, pp. 256-257, 1977.

[7] D. Bayındır and A. Dağal, "The Investigation of the Relationship between the Level of Metacognitive Awareness, Self-directed Learning Readiness and Academic Achievement of Preschool Teacher Candidates", Universal Journal of Educational Research, vol. 4, no. 11, pp. 2533-2540, 2016.

[8] D. Jonassen, J. Strobel and C. Lee, "Everyday Problem Solving in Engineering: Lessons for Engineering Educators", Journal of Engineering Education, vol. 95, no. 2, pp. 139-151, 2006.

[9] S. Loyens, J. Magda and R. Rikers, "Self-Directed Learning in Problem-Based Learning and its Relationships with Self-Regulated Learning", Educational Psychology Review, vol. 20, no. 4, pp. 411-427, 2008.

[10] M. Gick and K. Holyoak, "The cognitive basis of knowledge transfer", Transfer of learning: Contemporary research and applications, Elsevier, pp. 9-46, 1987.

[11] D. Jonassen, "Instructional design models for well-structured and III-structured problem-solving learning outcomes", Educational Technology Research and Development, vol. 45, no. 1, pp. 65-94, 1997. 
[12] R. Marra, S. Kim, C. Plumb, D. Hacker and S. Bossaller, "Beyond the Technical: Developing Lifelong Learning and Metacognition for the Engineering Workplace", in Proceedings of the Annual meeting of American Society for Engineering Education, Columbus Ohio, 2017. 